cians. The evolving legislation is a first step in a process that undoubtedly will continue to evolve over the foreseeable future. As Vice-President of Education for the Canadian Urological Association, I know we are working diligently to fill these gaps and provide educational programs that are fair-balanced, cutting edge and directed at the needs of our membership and the Canadian public.

Competing interests: Dr. Brock has received honoraria from Lilly, Coloplast, AMS, GSK, Abbott, Johnson and Johnson, Ferring and Actavis.

Correspondence: Dr. Gerry Brock, St. Joseph's Health Centre, Department of Urology, 268 Grosvenor St., London, 0N N6A 4V2; gebrock@sympatico.ca

\section{Changing times indeed}

\section{Peter Anderson, BSc, MD, FRCSC, MEd}

Division of Urology, Dalhousie University, Halifax, NS

Cite as: Can Urol Assoc J 2014;8(1-2):19. http://dx.doi.org/10.5489/cuaj.1932 Published online February 10, 2014.

The times are indeed changing! Although Canada is not yet the $51^{\text {st }}$ state of the Union, almost all pharmaceutical companies are subsidiaries or siblings of their American counterparts, so we can assume that whatever happens south of the $49^{\text {th }}$ parallel will likely occur here in due course. However, we have already made substantial changes in how physicians and industry interact ${ }^{1}$ in Canada, so the effects of the "sunshine laws" may be less dramatic than in the United States.

Nonetheless, it is sobering to realize that the registration fee to attend our Annual Meeting represents less than half of the true cost of the event. Loss of industry support will have a significant impact unless we can be innovative in our approach to this iconic activity. Stay tuned.

Competing interests: Dr. Anderson is currently President of the Canadian Urological Association.

\section{Reference}

1. CMA Guidelines for physicians in interactions with industry. http://policybase.cma.ca/dbtw-wpd/ Policypdf/PD08-01.pdf. Accessed January 16, 2014.

Correspondence: Dr. Peter Anderson, IWK Health Centre, Division, Box 9700, 5850 University Ave., B3K 6R8; peter.anderson@iwk.nshealth.ca 